\title{
Moratorium Sawit Jokowi dalam Perspektif Kebijakan Pembangunan Berkelanjutan ala Politik Hijau
}

\author{
Sekar Banjaran Aji ${ }^{1}$
}

\begin{abstract}
Abstrak
Pada fase terakhir pemerintahannya, Presiden Joko Widodo (Jokowi) menandatangani Instruksi Presiden (Inpres) tentang penghentian sementara (moratorium) perluasan lahan dan evaluasi perkebunan sawit. Regulasi ini tercantum dalam Inpres Nomor 8 tahun 2018 tentang Penundaan dan Evaluasi Perizinan Serta Peningkatan Produktivitas Perkebunan Sawit, ditandatangani Jokowi pada 19 September 2018. Kajian ini melihat apakah kebijakan Moratorium Sawit Jokowi dapat dikategorikan sebagai kebijakan hijau yang sesuai dengan Teori Politik Hijau sehingga berpihak untuk kepentingan lingkungan. Lebih jauh lagi, melihat seberapa solutif kebijakan moratorium sawit ini menyelesaikan masalah tata kelola lahan dan konflik yang mencederai sektor pemasok APBN terbanyak tahun 2017.
\end{abstract}

Kata kunci: Moratorium Sawit, Politik Hijau, Kebijakan Tata Kelola Lahan

\begin{abstract}
In the last phase of his administration, President Joko Widodo (Jokowi) approved the Presidential Instruction (Inpres) on the temporary suspension (moratorium) of clearing land and renewing plantations. Presidential Instruction Number 8 of 2018 concerning Delays and Evaluation of Licensing and Increased Productivity of Oil Palm Plantations, signed by Jokowi on September 19, 2018. This study refers to the Environmental Palm Moratorium policy. Furthermore, see the resolution of the palm oil moratorium policy solution to resolve land governance issues and conflicts that have hurt the supplier sector of the most state budget in 2017.
\end{abstract}

Keywords: Oil Palm Moratorium, Green Politics, Land Management Policy

\section{Pendahuluan}

Joko Widodo (Jokowi) merupakan Presiden yang berani menempatkan permasalahan degradasi lingkungan jadi masalah serius sehingga perlu dimani- festasikan dalam Nawacita. ${ }^{2}$ Beberapa kebijakan strategis kemudian dilahirkan, misalnya menggabungkan badan dan kementerian menjadi satu kementerian besar bernama Kementerian Lingkungan

${ }^{1}$ Penulis merupakan pengacara publik sekaligus peneliti Lembaga Studi dan Advokasi Masyarakat (ELSAM). Dia juga aktif dalam Koalisi Masyarakat Sipil yang mendorong perbaikan tata kelola sawit berkelanjutan di Indonesia.

${ }^{2}$ Riva Suastha, "WALHI Tagih Janji Jokowi Selesaikan Konflik Lingkungan”, https://www. cnnindonesia.com/nasional/20160602195942-20-135483/walhi-tagih-janji-jokowi-selesaikan-konfliklingkungan, diakses tanggal 1 Januari 2019. 
Hidup dan Kehutanan (KLHK). Kemudian, mereformasi Kementerian Kelautan dan Perikanan (KKP) yang kemudian dikenal sebagai kementerian yang bergigi.

Tahun 2016, Jokowi membentuk Badan Restorasi Gambut (BRG) yang diharapkan mampu merestorasi lahan-lahan gambut yang terbakar dan rusak parah. ${ }^{3}$ Hal tersebut menjadi sebuah peluang yang besar dan membuat gerakan lingkungan di Indonesia semakin percaya diri. Oleh karenanya, gerakan lingkungan memiliki harapan besar supaya Jokowi dapat menempatkan lingkungan menjadi prioritas.

Dalam konteks tersebut, diskursus politik hukum menjadi menarik untuk digali. Mahfud M.D berpendapat bahwa politik hukum adalah garis kebijakan resmi tentang hukum yang akan diberlakukan baik dengan pembuatan hukum baru maupun dengan penggantian hukum lama, dalam rangka mencapai tujuan negara. ${ }^{4}$ Sunaryati Hartono menyatakan, faktor-faktor yang akan menentukan politik hukum tidak semata-mata ditentukan oleh apa yang dicita-citakan pembentuk hukum, praktisi atau para teoretisi saja, namun ikut ditentukan pula oleh kenyataan serta perkembangan hu- kum di lain-lain negara serta perkembangan hukum internasional. ${ }^{5}$ Demikian membuat ruang lingkup politik hukum menjadi luas dan menarik untuk digali.

Salah satu yang menarik untuk dicermati adalah Instruksi Presiden (Inpres) di mana kebijakan ini memang dapat dibuat dalam berbagai macam bentuk dokumen tertulis yang bersifat membimbing, menuntun, memberi arahan kebijakan, dan mengatur suatu pelaksanaan tugas dan pekerjaan.

Inpres masuk dalam kategori Instruction to Officials dalam kerangka peraturan kebijakan atau "policy rule" yang dapat disebut juga sebagai "quasi legislation" oleh Jimly Asshiddiqie. ${ }^{6}$ Inpres bukan merupakan keputusan yang mengikat umum (semua orang, tiap orang). Inpres merupakan perintah atasan kepada bawahan yang bersifat individual, konkret dan sekali-kali (final, einmahlig) sehingga tidak dapat digolongkan dalam peraturan perundang-undangan (wetgeving) atau peraturan kebijakan (beleidsregel, pseudo-wetgeving). Inpres hanya dapat mengikat Menteri, kepala lembaga pemerintah non departemen, atau pejabat-pejabat pemerintahan yang berkedudukan di bawah Presiden dalam melak-

${ }^{3}$ Mongabay Indonesia, "Rangkuman: Melacak Komitmen Presiden Jokowi dalam Pengelolaan Lingkungan di Indonesia", https://www.mongabay.co.id/2016/07/31/rangkuman-melacak-komitmenpresiden-jokowi-dalam-bidang-pengelolaan-lingkungan-di-indonesia/, diakses tanggal 1 Januari 2019.

${ }^{4}$ Moh. Mahfud MD, Politik Hukum di Indonesia, (Jakarta: Raja Grafindo, 2014), hlm. 1.

${ }^{5}$ Sunaryati Hartono, Politik Hukum Menuju Satu Sistem Hukum Nasional, (Bandung: Alumni, 1991), hlm. 1.

${ }^{6}$ Letezia Tobing, "Perbedaan Keputusan Presiden Dengan Instruksi Presiden", https:/ / www.hukumonline.com/klinik/detail/lt50cf39774d2ec/perbedaan-keputusan-presiden-dengan-instruksi-presiden/, diakses tanggal 1 Januari 2019. 
sanakan penyelenggaraan pemerintahan. ${ }^{7}$ Dengan demikian, Inpres menjadi menarik karena posisinya yang spesifik dan menggambarkan secara jelas bagaimana Presiden menyikapi sesuatu dengan memerintahkan jajarannya.

Keberadaan Inpres Nomor 8 tahun 2018 tentang Penundaan dan Evaluasi Perizinan Serta Peningkatan Produktivitas Perkebunan Sawit (Inpres Moratorium) menjadi penting untuk dilihat dalam kacamata politik hukum mengingat kebijakan ini didorong oleh gerakan lingkungan beberapa organisasi masyarakat sipil. Dorongan tersebut mewakili banyak impian untuk menyelesaikan masalah dalam sektor perkelapasawitan terutama permasalahan lingkungan. Sehingga secara implisit, ada harapan bahwa kebijakan Inpres Moratorium ini menjadi kebijakan hijau sesuai semangat Teori Politik Hijau yang menempatkan keadilan antar generasi menjadi tujuan utama.

Tujuan penulisan ini ialah menganalisis politik hukum dari kebijakan Inpres Moratorium Sawit dan sejauh mana kesesuaiannya dengan Teori Politik Hijau yang dianggap sebagai penentu kebijakan berkelanjutan.

\section{Moratorium Sawit dalam Rekam Historis}

Kebijakan otorisasi legal untuk menunda sesuatu atau kewajiban tertentu selama batas waktu yang ditentukan (moratorium) bukan istilah baru. ${ }^{8}$ Istilah tersebut berasal dari Bahasa Latin, mora$r i$, yang berarti penundaan. Dalam konteks tata kelola hutan dan lahan, "moratorium" sudah lazim digunakan. Misalnya moratorium izin hutan dan gambut melalui Inpres Nomor 10 Tahun 2011 tentang Penundaan Pemberian Izin Baru dan Penyempurnaan Tata Kelola Hutan Alam Primer dan Lahan Gambut, memberi perintah kepada tiga menteri (Kehutanan, Dalam Negeri dan Lingkungan Hidup) dan kepala lima lembaga (Unit Kerja Presiden Bidang Pengawasan dan Pengendalian Pembangunan, Badan Pertanahan Nasional, Badan Koordinasi Penataan Ruang Nasional, Badan Koordinasi Survei dan Pemetaan Nasional dan lembaga yang dibentuk untuk mengelola REDD+), serta para gubernur dan bupati. Inpres ini menjelaskan tugas dan tanggung jawab masing-masing lembaga selama dua tahun sejak Inpres diterbitkan. ${ }^{9}$

Moratorium sebenarnya telah ada sejak era Pemerintahan Presiden Susilo

\footnotetext{
${ }^{7}$ Maria Farida Indrati, Ilmu Perundang-Undangan: Dasar dan Cara Pembentukannya, (Yogyakarta: Kanisius, 2007), hlm. 184.

${ }^{8}$ Dictionary, "Definition of Moratorium from the Cambridge Advanced Learner's Dictionary \& Thesaurus", https://dictionary.cambridge.org/dictionary/english/moratorium, diakses tanggal 2 Januari 2019.

${ }^{9}$ D Murdiyarso, et. al., "Moratorium Hutan Indonesia: Batu Loncatan Untuk Memperbaiki Tata Kelola Hutan?", https://www.cifor.org/library/3631/, diakses tanggal 2 Januari 2019.
} 
Bambang Yudhoyono (SBY). Mulai Inpres No.10/2011 tertanggal 20 Mei 2011 diperpanjang dengan Inpres No 6/2013. Terakhir, Jokowi melanjutkan moratorium dengan Inpres No.8/2015.

Selama dua rezim pemerintahan, kebijakan moratorium kurang memuaskan. Tata kelola hutan dan gambut belum baik. Hal ini terkonfirmasi dari dua fakta, pertama, masih ada pemberian izin kehutanan dan perkebunan oleh pemerintah melalui revisi-revisi areal moratorium dan pelepasan kawasan hutan. Revisi areal moratorium sejak 2011- 2013, mengurangi 5.055.089 hektare. Pada 2015, dengan menambah kembali areal moratorium 2.353.151 hektare. Inkonsistensi penerapan areal moratorium ini membuka peluang pemberian izin baru, baik izin usaha kehutanan maupun perkebunan melalui pelepasan kawasan hutan. ${ }^{10}$ Kedua, masih terjadi pembakaran hutan dan lahan masif dalam pembukaan perkebunan sawit, terutama di tiga pulau utama Indonesia, Sumatera, Kalimantan dan Papua. Bank Dunia mencatat, 2015 saja terdapat seluas 2,6 hektare lahan terbakar pada perkebunan sawit menyebabkan kerugian mencapai Rp221 triliun. $^{11}$

Kata kunci sawit dalam temuan hasil capaian Inpres Moratorium Hutan dan Gambut, membuat masyarakat sipil mengusulkan kebijakan yang lebih fokus terhadap komoditas sawit. Moratorium sawit tercantum dalam Inpres Moratorium yang ditandatangani Jokowi pada 19 September 2018. Moratorium ini bertujuan memberikan waktu bagi Pemerintah untuk mengevaluasi dan menata kembali izin perkebunan sawit dan meningkatkan produktivitas. ${ }^{12}$

Kebijakan yang diadvokasi masyarakat sipil kurang lebih dua tahun, akhirnya diterbitkan dalam bentuk Inpres tentang moratorium perluasan lahan dan evaluasi perkebunan sawit. Aturan ini jadi pemenuhan janji Jokowi dalam Hari Hutan Internasional di Kepulauan Seribu, 14 April 2016. ${ }^{13}$

Desakan masyarakat sipil yang dimotori oleh Sawit Watch, HuMA dan ELSAM untuk moratorium dikarenakan beberapa hal yakni: ${ }^{14}$

1. Produktivitas perkebunan sawit Indonesia yang rendah;

${ }^{10}$ Nurul Firmansyah, "Moratorium Izin Hutan dan Gambut, Berjilid-jilid (Tanpa) Ada Perbaikan?," https:/ / www.mongabay.co.id/2017/05/28/opini-moratorium-izin-hutan-dan-gambut-berjilid-jilidtanpa-ada-perbaikan/, diakses tanggal 3 Januari 2019.

${ }^{11}$ Ibid.

12 Sapariah Saturi, “Akhirnya, Inpres Moratorium Perkebunan Sawit Terbit," https://www. mongabay.co.id/2018/09/20/akhirnya-inpres-moratorium-perkebunan-sawit-terbit/, diakses tanggal 2 Januari 2019.

${ }^{13}$ Ibid.

${ }^{14}$ Anonim, "Policy Brief Rasionalitas Moratorium Sawit", http://sawitwatch.or.id/wp-content/ uploads/2017/07/Full-rasionalitas-moratorium-sawit2.pdf, diakses tanggal 2 Januari 2019. 
2. Berpotensi melanggengkan kebakaran hutan dan lahan;

3. Eskalasi konflik agraria seiring dengan ekspansi perkebunan;

4. Realisasi pembangunan perkebunan kelapa sawit yang tidak sesuai dari perencanaan bahkan ditemukan kebun tanpa dilengkapi izin;

5. Praktik perbudakan modern di perkebunan sawit;

6. Ketidakselarasan kebijakan dalam ekosistem gambut.

Pada rezim sebelumnya, Pemerintah Indonesia telah berkomitmen untuk memperbaiki tata kelola hutan dan lahan gambut dengan mengeluarkan Inpres Nomor 10 tahun 2011 tentang Penundaan Pemberian Izin Baru dan Penyempurnaan Tata Kelola Hutan Alam Primer dan Lahan Gambut yang berlaku selama dua tahun. Kebijakan ini diperpanjang dengan terbitnya Inpres Nomor 6 Tahun 2013 dan kemudian diperpanjang lagi oleh Inpres Nomor 8 tahun 2015.

Perbedaan yang mencolok antara Inpres Moratorium Hutan dan Gambut dengan Inpres Moratorium Sawit terletak pada klausa mandat evaluasi izin. Dalam Inpres Moratorium Hutan dan Gambut, ketiadaan klausa evaluasi izin menjadi salah satu penyebab tidak ada ruang penyelesaian konflik lahan antara masyarakat adat, lokal dengan pemerintah dan perusahaan, sebab perlindungan, pengukuhan kebijakan penundaan pemberian izin dan penguatan atas hak dan ruang kelola rakyat belum sepenuhnya dijalankan. ${ }^{15}$

Belajar dari kekurangan Inpres Moratorium Hutan dan Gambut maka dalam Inpres Moratorium Sawit terdapat klausa evaluasi perizinan yang bersifat 'keterlanjuran'. Caranya dengan mengkaji dampak lingkungan, sosial dan kesesuaian dengan tata ruang yang dilakukan KLHK Jika dilihat dari perspektif reforma agraria, evaluasi izin semestinya bisa membantu pekebun sawit rakyat mendapatkan pengakuan hak hingga memperoleh pemodalan. Pelaksanaan aturan ini, semestinya bersamaan dengan implementasi Peraturan Presiden Nomor 88/2017 tentang Penyelesaian Penguasaan Tanah dalam Kawasan Hutan, khusus perkebunan sawit di kawasan hutan. Keduanya, merupakan rangkaian kebijakan di bawah koordinasi Kementerian Koordinator Perekonomian (Kemenko Perekonomian). ${ }^{16}$

${ }^{15}$ Anonim, “Enam Tahun Memperbaiki Tata Kelola Hutan dan Lahan Gambut: Sebuah Evaluasi atas Pelaksanaan Instruksi Presiden Tentang Penundaan Pemberian Izin Baru dan Penyempurnaan Tata Kelola Hutan Alam Primer dan Lahan Gambut", http://www.mongabay.co.id/wp-content/ uploads/2017/05/Kertas-Kebijakan-Moratorium-dari-Koalisi.pdf, diakses pada tanggal 3 Mei 2019.

${ }^{16}$ Lusia Arumingtyas dan Indra Nugraha, "Akhirnya, Inpres Moratorium Perkebunan Sawit Terbit", https:/ / www.mongabay.co.id/2018/09/20/akhirnya-inpres-moratorium-perkebunan-sawitterbit/, diakses tanggal 2 Januari 2005. 
Dari kronologi kebijakan moratorium dalam konteks perbaikan tata kelola lahan dalam kedua Inpres tersebut, politik hukum yang melatarbelakangi penyusunannya tidak berasal dari inisiatif Pemerintah semata. Masyarakat sipil cukup berperan dalam mengadvokasi isu hingga menghasilkan sebuah kebijakan serta memastikan suatu kebijakan berkelanjutan.

\section{Politik Hijau dan Kebijakan Pembangunan Berkelanjutan}

Terdapat beberapa pendapat ahli mengenai teori ini.

\begin{tabular}{|c|c|c|c|}
\hline Eckersley & Goddin & Barry & Dobson \\
\hline $\begin{array}{l}\text { Pandangan } \\
\text { ekosentris ini } \\
\text { menempatkan } \\
\text { fokus utamanya } \\
\text { pada lingkungan } \\
\text { atau ekosistem } \\
\text { dalam aspek } \\
\text { kehidupan }\end{array}$ & $\begin{array}{l}\text { Mengedepankan } \\
\text { sumber nilai } \\
\text { sebagai fakta dari } \\
\text { sesuatu yang } \\
\text { dibentuk oleh } \\
\text { proses alamiah } \\
\text { sejarah dan lebih } \\
\text { dari sekedar } \\
\text { peran manusia }\end{array}$ & $\begin{array}{l}\text { Tiga prinsip } \\
\text { utama antara lain } \\
\text { teori distribusi } \\
\text { (intergenerasional) } \\
\text { keadilan, } \\
\text { komitmen } \\
\text { terhadap proses } \\
\text { demokratisasi } \\
\text { dan usaha } \\
\text { untuk mencapai } \\
\text { keberlangsungan } \\
\text { ekologi }\end{array}$ & $\begin{array}{l}\text { Menolak pandangan } \\
\text { antroposentrisme } \\
\text { seperti yang telah } \\
\text { diungkapkan } \\
\text { Ekscersly sebelumnya. } \\
\text { Kemudian, perlu ada } \\
\text { batasan pertumbuhan, } \\
\text { yang merupakan } \\
\text { penyebab munculnya } \\
\text { krisis lingkungan } \\
\text { secara alami. }\end{array}$ \\
\hline
\end{tabular}

\section{Tabel 1. Perbandingan Pendapat Ahli Mengenai Teori Politik Hijau}

John Barry jadi satu dari empat tokoh Teori Politik Hijau yang punya kriteria yang sederhana dan jelas indikatornya. Tiga prinsip utama ini merupakan konsepsi yang mewakili makna dari pusat Politik Hijau. Prinsip ini digunakan sebagai sarana untuk menjelaskan konsepsi dari teori hijau, seperti dalam memahami kelangsungan dari eko-otoritarianisme yang menjadi salah satu usaha keberlanjutan bagi biaya demokrasi dan keadilan sosial.
Arah kebijakan hukum di bidang lingkungan hidup itu disebut dengan politik hukum lingkungan. Politik hukum lingkungan merupakan arah kebijakan hukum yang ditetapkan oleh negara atau pemerintah untuk mencapai tujuan dan sasaran dari perlindungan dan pengelolaan lingkungan hidup.

Namun, dalam kenyataannya hukum lingkungan seolah tidak mampu menjalankan fungsinya dengan baik dengan munculnya berbagai masalah ling- 
kungan hidup, salah satu penyebab masalah-masalah lingkungan hidup adalah belum dipahami, dilaksanakan, dan di- tegakkannya prinsip dan norma hukum lingkungan secara komprehensif sesuai dengan politik hukumnya.

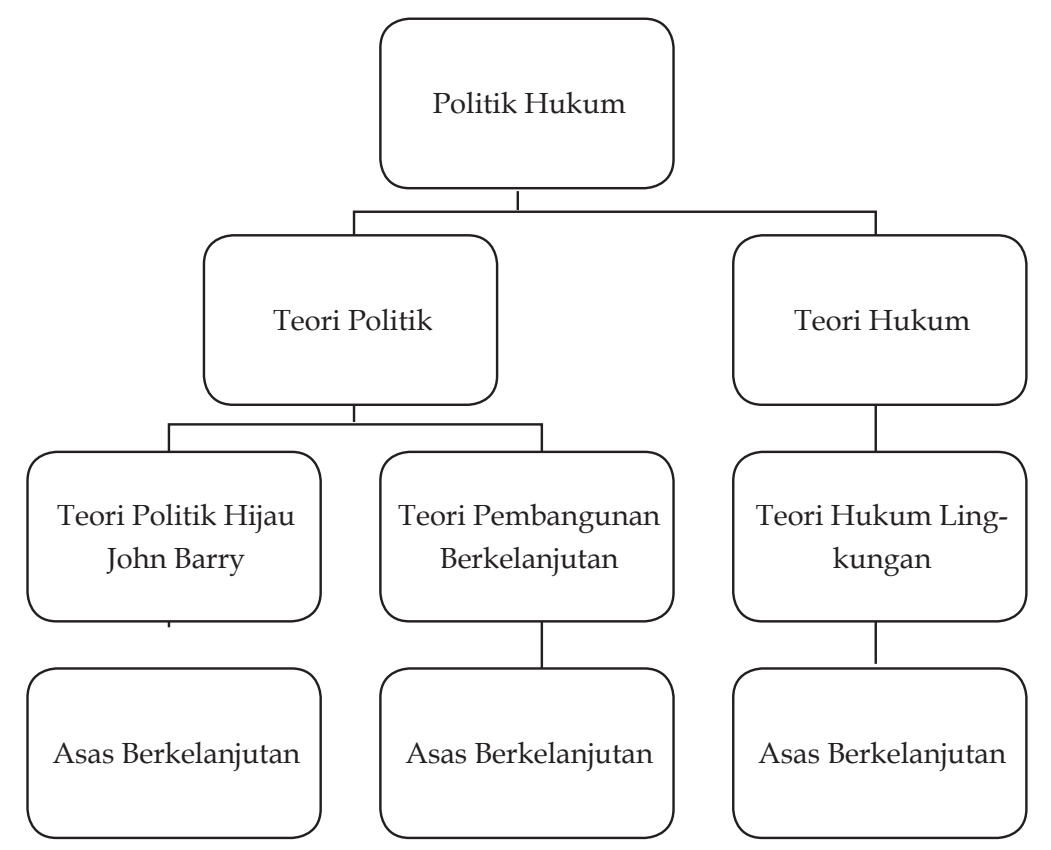

\section{Gambar 1. Keterkaitan antara Politik Hukum dan Teori Lain}

Ada dua teori yang dapat dipakai untuk mengaji kebijakan moratorium yakni teori politik hijau dengan menggunakan kebijakan teori pembangunan berkelanjutan sebagai perspektif yang dianalisis dengan teori politik hijau. Keduanya dapat dipergunakan secara bersamaan karena memiliki banyak kriteria yang sama yakni keinginan mewujudkan keadilan antar generasi. Teori politik hijau John Barry mencita-citakan distribusi keadilan antar generasi (intergenerasional). Hal tersebut sama persis dengan, pengertian Emil Salim tentang pembangunan berkelanjutan mengandaikan solidaritas transgenerasi, di mana pembangunan ini me- mungkinkan generasi sekarang untuk meningkatkan kesejahteraannya, tanpa mengurangi kemungkinan bagi generasi masa depan untuk meningkatkan kesejahteraannya.

Berkaca lewat Teori Hukum Lingkungan, hal tersebut juga selaras dengan salah satu "asas keberlanjutan" sebagai asas pengelolaan lingkungan hidup dalam konteks teori hukum lingkungan. Asas berkelanjutan yang termuat dalam Pasal 2 Undang-Undang No. 32 Tahun 2009 mengandung makna setiap orang memikul kewajibannya dan tanggung jawab terhadap generasi mendatang, dan terhadap sesamanya dalam satu genera- 
si, dengan melakukan upaya pelestarian daya dukung ekosistem dan memperbaiki kualitas lingkungan hidup.

Teori-teori tersebut memiliki kesamaan yang dapat dimaknai menjadi menjadi kesatuan yang melatarbelakangi terbentuknya kebijakan. Teori Politik Hijau John Barry, Teori Pembangunan Berkelanjutan, dan Teori Hukum Lingkungan selaras mengedepankan keadilan antar generasi sebagai tujuan bersama. Dengan demikian, generasi hari ini dalam membuat kebijakan haruslah memikirkan kewajibannya dan tanggung jawab terhadap generasi mendatang atau dengan kata lain kebijakan tersebut haruslah berasaskan keberlanjutan. Selanjutnya, penulis akan menyebutnya dengan istilah kebijakan berkelanjutan.

\section{Moratorium Sawit Jokowi Sebagai Kebijakan Berkelanjutan}

Apakah moratorium dalam kerangka kerja Jokowi termasuk kebijakan berkelanjutan? Tulisan ini akan fokus menganalisis kebijakan moratorium itu sendiri disandingkan dengan indikator keberlanjutan.

\section{A. Komitmen Politik Kebijakan}

Rezim Jokowi berada dalam posisi tidak menyenangkan jika dilihat dalam kontestasi perkelapasawitan. Begitu banyak kepentingan baik Negara, korporasi, petani dan gerakan lingkungan beradu sepanjang Jokowi berkuasa. Mulai dengan fakta bahwa pada level dunia, Indonesia adalah produsen dan eksportir kelapa sawit terbesar di dunia, yang bersama Malaysia, menghasilkan 85-90 persen total minyak sawit di dunia. ${ }^{17}$ Menurut RSPO (Roundtable on Sustainable Palm Oil), Indonesia berkontribusi sebesar 58\% dari produksi minyak kelapa sawit berkelanjutan yang bersertifikat RSPO di seluruh dunia. Sementara produksi minyak kelapa sawit berkelanjutan yang telah mendapat sertifikat RSPO secara global saat ini mencapai 12,15 juta ton. Ini sama saja dengan $17 \%$ dari total produksi minyak kelapa sawit dunia. ${ }^{18}$

Sementara data dari Direktorat Jenderal Perkebunan Kementerian Pertanian menyebut kelapa sawit telah menyumbang devisa kepada negara mencapai Rp239,4 triliun. ${ }^{19} \mathrm{Hal}$ tersebut membuat sawit dianggap sebagai emas hijau yang menempati urutan pertama penyumbang devisa dari data BPS pada

${ }_{17}$ Anonim, "Minyak Kelapa Sawit", https://www.indonesia-investments.com/id/bisnis/komoditas/ minyak-sawit/item166, diakses tanggal 13 Oktober 2018.

${ }^{18} \mathrm{Ibid}$.

${ }^{19}$ Agustiyanti, “Kementan Klaim Sawit Sumbang Devisa Negara Rp239 Triliun”, https://www. cnnindonesia.com/ekonomi/20170829150806-92-238106/kementan-klaim-sawit-sumbang-devisanegara-rp239-triliun, diakses tanggal 13 Oktober 2018. 
2017 dan hingga Oktober, mengalahkan minyak dan gas serta sektor pariwisata. ${ }^{20}$ Menurut data BPS, jumlah total luas area perkebunan sawit di Indonesia pada 2017 mencapai sekitar 11.9 juta hektare, hampir tiga kali lipat dari luas area di tahun 2000 (sekitar 4 juta hektare lahan di Indonesia dipergunakan untuk perkebunan kelapa sawit). Jumlah ini diduga akan bertambah menjadi 13 juta hektare pada tahun $2020 .{ }^{21}$

Resolusi non-legislatif Uni Eropa terkait Kelapa Sawit dan Deforestasi diluncurkan pada bulan April tahun 2017 oleh Parlemen Uni Eropa. Resolusi non-legislatif adalah resolusi yang tidak melalui normalnya prosedur legislatif Uni Eropa, oleh karena itu, resolusi non-legislatif hanya bersifat soft law dan tidak mengikat. Resolusi ini fokus untuk mendorong Uni Eropa untuk melakukan aksi-aksi dalam menghadapi deforestasi, khususnya yang diakibatkan oleh perkebunan kelapa sawit. Dengan kata lain, resolusi tersebut menitikberatkan kebutuhan untuk menghadapi dampak lingkungan dan sosial dari produksi kelapa sawit, khususnya terkait biodiversitas, perubahan iklim, dan emisi gas rumah kaca, serta hak asasi manusia dan kesehatan dari perkebunan kelapa sawit di negaranegara produsen..$^{22}$

Sementara itu, Resolusi Parlemen Uni Eropa tentang "Minyak Kelapa Sawit dan Deforestasi Hutan Tropis" berisi dua poin penting terkait perkebunan kelapa sawit di Indonesia. Pertama, deforestasi global terjadi karena adanya peningkatan pertumbuhan dan konsumsi dari komoditas pertanian, termasuk minyak kelapa sawit. Proses pembukaan lahan untuk perkebunan dengan membakar hutan telah mengakibatkan bencana asap tahun 2015 yang berdampak pada 69 juta orang. Dengan demikian, Indonesia menjadi salah satu kontributor utama terhadap pemanasan global. Kedua, Parlemen Uni Eropa menyatakan bahwa operasi perkebunan kelapa sawit terkait dengan pelanggaran HAM. Pelanggaran yang terjadi antara lain adalah pekerja anak, penggusuran, diskriminasi terhadap masyarakat adat, kekerasan dan lain-lain. Selain itu, Eropa mengusulkan resolusi untuk melarang penggunaan minyak kelapa sawit dalam biofuel pada $2020 .{ }^{23}$

${ }^{20}$ Martin Sihombing, "Beginilah Geliat Industri Sawit, Si Emas Hijau”, http:/ /industri.bisnis.com/ read /20180205/99/734393/beginilah-geliat-industri-sawit-si- , diakses tanggal 13 Oktober 2018.

${ }^{21}$ Ibid.

${ }^{22}$ Kania Mezariani G, “Kelapa Sawit: Antara Kebijakan Ketahanan Energi Dan Climate Change Uni Eropa, Serta Respon Pemerintah Indonesia”, http:/ / perpustakaan.elsam.or.id/index.php?p=show_detail\&id=15289 \&keywords=kelapa+sawit, diakses tanggal 9 Oktober 2018.

${ }^{23}$ Ibid. 
Dalam perkembangan terakhir, Dewan dan Komisi Eropa menyepakati akan memberikan tambahan waktu bagi Indonesia dan Malaysia, meskipun ketiga pihak membuahkan kompromi terkait impor minyak sawit dari Indonesia dan Malaysia pada pertemuan tripartit antara Parlemen Juni 2018. Kandungan minyak sawit dalam biodiesel nantinya tidak lagi akan termasuk sasaran iklim Uni Eropa dan baru akan dilarang sepenuhnya pada 2030. Uni Eropa juga memutuskan akan mempertahankan volume impor serupa 2019 dan akan mengurangi impor minyak sawit secara perlahan mulai tahun 2023. ${ }^{24}$

Setelah dinamika tersebut tidak lagi dibahas oleh media, barulah Inpres Moratorium Sawit terbit pada September 2018. Walaupun terlambat, kebijakan moratorium ini cukup ampuh memberikan efek kejut pada pasar. Hal tersebut terbukti pada periode 7-23 September 2018, harga tandan buah segar (TBS) kelapa sawit naik sebesar Rp23 per kilogram. Kenaikan terjadi dari harga Rp1473 pada periode sebelumnya, menjadi Rp1496 perkilogram untuk periode ini. ${ }^{25}$

Kejadian kenaikan harga TBS memang belum dapat diklaim bahwa Inpres Moratorium Sawit merupakan kebijakan berkelanjutan. Dalam Teori Politik Hijau John Barry setidaknya ada tiga hal yang harus diuji yakni teori distribusi (intergenerasional) keadilan, komitmen terhadap proses demokratisasi, dan usaha untuk mencapai keberlangsungan ekologi. Apabila ketiga hal tersebut tercapai, barulah Inpres Moratorium dapat dilekati dengan sebutan kebijakan berkelanjutan.

Pertama, unsur distribusi manfaat atau keadilan antar generasi dalam Inpres Moratorium ini belum terlihat jika dilihat dalam konteks jangka waktu berlakunya Inpres Moratorium. Instruksi ini berlaku hanya tiga tahun (2018-2021). Periode implementasi Inpres di bawah pemerintahan ini hanya satu tahun (hingga Oktober 2019). Apabila Inpres ini berakhir masanya dan masih ada kegiatan yang belum dikerjakan, pun tidak ada klausul untuk memperpanjang moratorium sawit, sebagaimana ada dalam Inpres penundaan izin baru di hutan primer dan lahan gambut.

Dalam masa efektif jabatan Presiden Jokowi 2014-2019, proses maksimal pelaksanaan Inpres moratorium ini hanya satu tahun. Per Februari 2019, sudah lima bulan sejak Inpres moratorium dirilis, Tim Kerja yang dimandatkan belum terbentuk. Sementara Inpres moratorium mengamanatkan sistem pelaporan

${ }^{24}$ Hans Spross, “Uni Eropa Tunda Larangan Sawit Hingga 2030”, https://www.dw.com/id/unieropa-tunda-larangan-sawit-hingga-2030/a-44315242, diakses tanggal 26 Januari 2019.

${ }^{25}$ Fitri Amalia, "Update Harga TBS Kelapa Sawit September 2018, Semakin Membaik", http:// jambi.tribunnews.com/2018/09/10/update-harga-tbs-kelapa-sawit-7-23-september-2018-semakinmembaik, diakses tanggal 26 Januari 2019. 
kemajuan pelaksanaan kebijakan dilakukan Tim Kerja setiap enam bulan. Pelaporan fase pertama akan jatuh tempo pada bulan Maret 2019, tidak akan dapat disebut pelaporan hasil kerja jika Tim Kerja belum terbentuk di bulan Februari 2019.

Dalam shadow report yang dibuat kelompok masyarakat sipil terkait capaian semester pertama dari implementasi Inpres Moratorium Sawit, disebutkan bahwa per April 2019, Kemenko Bidang Perekonomian selaku koordinator pelaksanaan Moratorium Sawit sedang menyiapkan Standar Operasional (SOP) untuk penyusunan pemetaan dan validasi data. SOP tersebut akan berisi data mengenai tipologi permasalahan sawit dan Kawasan hutan yang nantinya akan direkomendasikan ke kementerian teknis. Kemenko Bidang Perekonomian juga sudah menentukan 7 provinsi yang akan menjadi prioritas pelaksanaan Inpres Moratorium Sawit, provinsi tersebut antara lain Jambi, Riau, Sumatera Utara, Sumatera Selatan, Kalimantan Barat, Kalimantan Tengah dan Timur.
Perkembangan tersebut tergolong sangat lambat sebab semestinya 6 (enam) bulan pertama sudah ada laporan yang diberikan kepada Presiden berupa capaian pelaksanaan Inpres. Dampak dari belum selesainya SIP penyusunan pemetaan dan validasi data menyebabkan tidak tercatatnya praktik-praktik baik dari daerah. Akhirnya, beberapa Provinsi dan Kabupaten sudah meresponsnya dengan komitmen kebijakan publik seperti Provinsi Nangroe Aceh Darusalam, Kabupaten Buol (Sulawesi Tengah), dan Kabupaten Sanggau (Kalimantan Barat) tidak terdokumentasi dan mendapatkan apresiasi yang baik.

Fenomena yang terjadi dalam fase pertama pelaporan merupakan capaian yang kurang baik. Jika hal tersebut tidak diperbaiki pada fase kedua, belum dapat dipastikan seluruh capaian tercapai, sebab fase ketiga terjadi pasca pemilu. Suksesi kepemimpinan mungkin saja mengubah struktur birokrasi atau kebijakan. ${ }^{26}$

Prasyarat teori distribusi harus memberikan manfaat demi terciptanya keadilan antar generasi. Kondisi ini dapat dicapai dengan kebijakan yang berjangka

${ }^{26}$ Hal tersebut pernah terjadi dalam pembubaran Badan Pengelola Penurunan Emisi dari Deforestasi dan Degradasi Hutan (BP-REDD+) dan Dewan Nasional Perubahan Iklim (DNPI). Kedua Lembaga tersebut dibentuk dalam rezim SBY, dan ketika terjadi perubahan ke rezim Jokowi, kedua Lembaga tadi dibubarkan melalui Perpres 16 Tahun 2015 yang ditandatangani Presiden Jokowi pada 21 Januari 2015. Ichwan Susanto, "Presiden Jokowi Bubarkan BP-REDD dan DNPI", https://sains. kompas.com/read/2015/01/28/18352191/Presiden.Jokowi.Bubarkan.BP-REDD.dan.DNPI, diakses tanggal 1 Mei 2019.

${ }^{27}$ Joko Waluyo, “Urgensi Kebijakan Moratorium Perkebunan Kelapa Sawit di Indonesia”, https:/ / www.tuk.or.id/2017/09/17/urgensi-kebijakan-moratorium-perkebunan-kelapa-sawit-di-indonesia/, diakses tanggal 3 Mei 2019. 
panjang. Hal ini mengingat kondisi bahwa tidak semua kebijakan akan langsung terlihat dampaknya dalam sekejap mata. Misalnya, dari analisis tentang urgensi kebijakan moratorium perkebunan sawit di Indonesia yang dilakukan Walhi bersama Kemitraan, TuK Indonesia, Sawit Watch, dan Auriga tahun $2017^{27}$ tak ada perubahan signifikan dari implementasi Inpres sebelumnya. Kebijakan moratorium tak mengurangi struktur penguasaan sumber daya alam, khususnya di perkebunan sawit skala besar yang dikuasai segelintir penguasa ekonomi. Waktu pemulihan jasa layanan alam tidak sebanding dengan laju kerusakan yang dihasilkan dari sebuah perizinan. Oleh karenanya, Walhi menawarkan kebijakan moratorium yang kuat, yakni dengan tak lagi memberikan izin kepada industri kebun kayu, sawit, dan tambang dalam kurun waktu minimal 25 tahun sembari secara aktif pemerintah melakukan kaji ulang dan audit perizinan yang sudah ada, yang ditengarai banyak melakukan pelanggaran hukum serta perundangundangan dan kejahatan korupsi.

Kedua, prasyarat tentang komitmen demokratitasasi dalam menjalankan suatu kebijakan dalam Inpres Moratorium dapat dilihat secara eksplisit dengan melihat aktor yang dilibatkan. Demokratisasi adalah suatu proses yang demokratis. Dalam teorinya, Scumpeter menggagas dua dimensi teoritik yang dapat dipakai sebagai acuan untuk menyebut demokrasi, yaitu: (1) seberapa tinggi tingkat kontestasi, kompetisi atau oposisi yang dimungkinkan, dan (2) seberapa banyak warga negara memperoleh kesempatan berpartisipasi dalam kompetisi politik itu. ${ }^{28}$ Semakin banyak pembagian wewenang antar Pemerintah dan semakin masyarakat yang dapat terlibat dalam pelaksanaan kebijakan, maka proses demokrasi tersebut sedang berjalan.

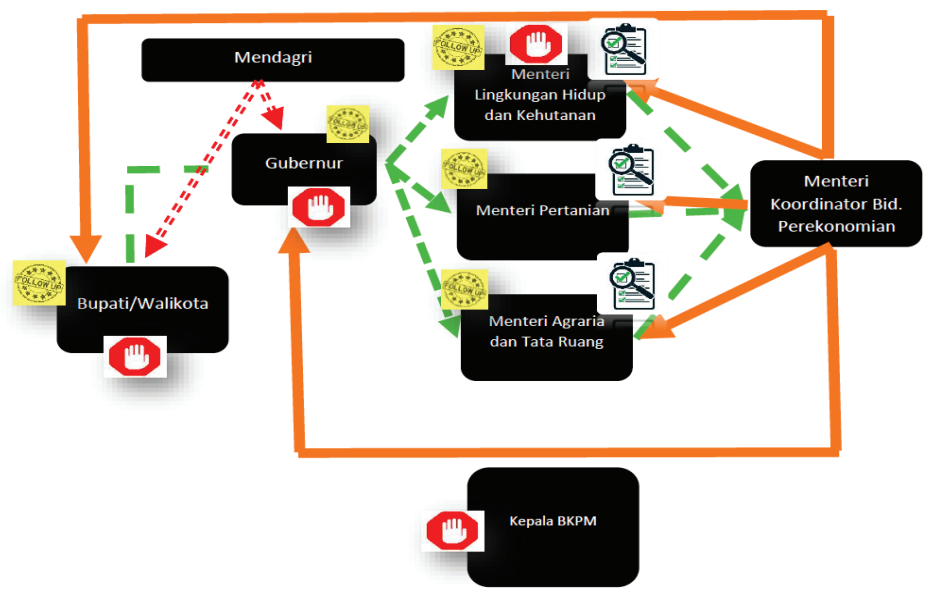

Gambar 2. Alur Koordinasi antar Pemerintah dalam Inpres Moratorium Sawit ${ }^{29}$

${ }^{28}$ M. Mas'oed, Ilmu Hubungan International: Disiplin dan Metodologi, (Jakarta: LP3ES, 1994), hlm. 9.

${ }_{29}^{29}$ Anonim, "Analisis Substansi Inpres Moratorium Sawit 2018", https://madaniberkelanjutan. id/2018/09/28/analisis-substansi-inpres-moratorium-sawit-2018/, diakses tanggal 28 Januari 2019. 
Dalam bagan tersebut secara sederhana dapat dilihat bahwa hubungan antara delapan pejabat dalam Inpres ini dapat dilihat pada di atas. Panah hijau mewakili alur pelaporan data, panah merah mewakili fungsi pembinaan, dan panah oranye mewakili penyampaian rekomendasi/hasil rapat koordinasi. Sementara tanda stop mewakili pejabat negara yang diperintahkan menunda penerbitan izin terkait kelapa sawit (di kawasan hutan) sesuai dengan kewenangannya masing-masing dan gambar suryakanta mewakili pejabat negara yang harus melakukan evaluasi izin terkait kelapa sawit. ${ }^{30}$

Dalam hal ini, terlihat bahwa KLHK salah satu aktor yang diberi peran strategis untuk melakukan tiga hal di atas sekaligus, yakni: penundaan izin, evaluasi, dan langkah-langkah tindak lanjut (termasuk penegakan hukum). Sementara itu, Kemenko Bidang Perekonomian tidak punya banyak kewenangan kecuali mengkoordinasikan pemangku kebijakan lain.

Terkait proses demokratisasi dalam posisi ini terlihat bahwa tidak ada himbauan dari Presiden kepada para aktor yang diberi mandat untuk mendengarkan suara masyarakat sipil atau melibatkan masyarakat sipil dalam implementasi kebijakan. Partisipasi publik terlihat menjadi keniscayaan dalam Inpres Mo- ratorium ini. Dengan demikian Inpres Moratorium ini tidak memenuhi prasyarat demokratisasi.

Ketiga, prasyarat kebijakan harus menjadi usaha untuk mencapai keberlangsungan ekologi menjadi hal yang paling sulit diukur karena bentuknya berupa implementasi kebijakan. Hal ini mengingat kebijakan yang dimaksud juga masih dalam tahap awal implementasi. Dengan alasan tersebut, khusus dalam bagian ini, Penulis akan menganalisis dari titik berat kebijakan. Apabila titik beratnya adalah usaha simultan untuk melindungi fungsi kelestarian lingkungan hidup dan bukan ekonomi jangka pendek, maka kebijakan tersebut patut dikategorikan sebagai kebijakan yang pro keberlangsungan ekologi.

Secara implisit dapat diartikan bahwa kebijakan ini merupakan manifestasi dari usaha mencapai keberlangsungan ekologi dengan menyelesaikan silang sengkarut perkelapasawitan melalui moratorium. Jika melihat ide awal ketika kebijakan ini dibuat memang salah satunya untuk menyelesaikan masalah lingkungan akibat sawit. Menurut Menteri Koordinator Bidang Perekonomian, Darmin Nasution, Inpres Moratorium Sawit merupakan solusi berbagai persoalan tata kelola. Ia juga sejalan dua aturan lain, yakni Inpres Percepatan Penyelesaian Tanah dalam Kawasan Hutan dan Inp-

\footnotetext{
${ }^{30}$ Ibid.
} 
res Reforma Agraria. Jangan mengartikan bahwa Pemerintah akan berhenti menambah produksi minyak sawit. Pemerintah memberikan waktu tiga tahun membereskan semua persoalan di perkebunan sawit, termasuk di dalam kawasan hutan. ${ }^{31}$

Berdasarkan ketiga prasyarat Teori Politik Hijau hanya ada satu yang terpenuhi yakni mencapai keberlangsungan ekologi dalam tataran ide imajinasi awal. Dalam dua prasyarat lain masih terganjal bahkan dalam tataran eksplisit kebijakan.

\section{B. Impian Melampaui Evaluasi Izin dalam Moratorium Sawit}

Menilik kebijakan yang serupa sebelumnya yakni Inpres No. 6 Tahun 2017 soal penundaan dan penyempurnaan tata kelola pemberian izin baru hutan alam primer dan lahan gambut atau Inpres Moratorium serupa di rezim SBY, ternyata tidak pernah menyinggung soal evaluasi. Namun dalam Inpres Moratorium Sawit ini muncul mandat evaluasi pada KLHK untuk melakukan evaluasi atas pelepasan atau tukar menukar kawasan hutan yang telah diberikan kepada perkebunan kelapa sawit skala besar untuk menemukan kawasan hutan produktif yang belum dikonversi yang ter- dapat di wilayah konsesi perkebunan yang masih bisa diselamatkan atau untuk menemukan terjadinya pelanggaran hukum, termasuk perkebunan kelapa sawit yang beroperasi di dalam kawasan hutan, beroperasi tanpa izin yang sesuai, atau pelanggaran tata ruang. Berdasarkan evaluasi yang dilakukan, KLHK melalui rekomendasi dari Gubernur dapat mengembalikan kawasan yang memiliki hutan produktif di dalamnya menjadi kawasan hutan. Evaluasi izin yang telah diterbitkan adalah sebuah terobosan jika dibandingkan dengan kebijakan moratorium sebelumnya.

Hal tersebut membuat ada sebuah impian besar yang dilekatkan oleh Masyarakat Sipil pada Inpres Moratorium. ${ }^{32}$ Pertama, moratorium sawit setidaknya menghentikan izin pembukaan lahan sawit baru untuk tiga tahun ke depan. Itu menjadi harapan terbentuknya keseimbangan baru di pasar minyak sawit. Dalam satu dekade terakhir, maraknya izin pembukaan lahan telah menyebabkan produksinya meningkat. Tapi kenaikannya tak seimbang dengan permintaan sehingga terjadi kelebihan produksi yang mencapai 4,8 juta ton. Akibatnya, harga jualnya menjadi jatuh. Menilik lahan hutan yang dikonversi ke lahan sawit, Indonesia telah kelebihan lahan sekitar 960

31 Indra Nugraha, "Menteri Lingkungan Bakal Evaluasi 2,3 Juta Hektar Kebun Sawit di Kawasan Hutan”, https:/ / www.mongabay.co.id/2018/10/20/menteri-lingkungan-bakal-evaluasi-23-juta-hektar-kebun-sawit-di-kawasan-hutan/, diakses tanggal 4 Januari 2019.

${ }^{32}$ Wiko Saputra, “Selamat Datang Moratorium Sawit!", Tempo, 26 September 2018. 
ribu hingga 1 juta hektare. ${ }^{33}$

Kedua, moratorium adalah momentum untuk penataan lahan sawit dan memperkuat legalitasnya. Saat ini luas lahan sawit mencapai 11.9 juta hektare dan keberadaan lahannya sering kali bermasalah. Salah satunya berasal dari konversi hutan alam yang memicu deforestasi. Auriga mencatat, 3,4 juta hektare lahan yang sudah ditanami sawit berada di dalam kawasan hutan. ${ }^{34}$

Tidak ajegnya tata laksana perizinan lahan sawit juga menjadi pemicu konflik lahan. Tak hanya menerabas kawasan hutan, lahan-lahan itu juga tumpang-tindih dengan izin lainnya, seperti izin hutan tanaman industri dan pertambangan. Banyak juga izin yang berkonflik dengan masyarakat karena proses pengalihan haknya tak sesuai aturan. Moratorium sawit salah satunya bertujuan menyelesaikan hal itu.

Ketiga, mendukung program reforma agraria. Marwah moratorium adalah juga perbaikan redistribusi lahan. Banyak izin lahan sawit yang berasal dari pelepasan kawasan hutan tapi tidak didistribusikan kepada masyarakat dalam bentuk program kemitraan inti-plasma oleh perusahaan. Seharusnya, dalam setiap pelepasan kawasan hutan, perusahaan wajib menyerahkan 20 persen lahan kepada masyarakat. ${ }^{35}$

Berangkat dari tiga poin tersebut, tata kelola lahan menjadi kunci pamungkas dalam menjamin diterapkannya prinsip pembangunan berkelanjutan, mengingat selama ini izin menjadi awal untuk menentukan legalitas suatu lahan sawit. Ketika proses pemberian izin sudah ditunda, maka semestinya sejalan dengan hal tersebut proses evaluasi izin yang sudah diberikan atau memastikan bahwa seluruh lahan tutupan yang dibuka sesuai dengan sebagaimana mestinya untuk kemaslahatan bagi masyarakat.

Mempersoalkan tumpang tindih lahan antara kawasan hutan dengan perkebunan sawit dalam Inpres Moratorium ini, tujuannya tak lepas dari keberadaan perkebunan sawit dalam kawasan hutan yang sangat mungkin belum memiliki status jelas atas lahannya. Studi UGM menyebutkan bahwa terdapat 2,3 juta hektare perkebunan sawit dalam kawasan hutan alias tumpang tindih. ${ }^{36}$ Prob-

${ }^{33}$ Dewi Purningsih, "Inpres Moratorium Perkebunan Sawit Donong Penyerapan CPO”, https:/ / www.greeners.co/berita/inpres-moratorium-perkebunan-sawit-dorong-penyerapan-cpo/, diakses tanggal 3 Mei 2019.

${ }^{34}$ Wiko Saputra, op., cit.

${ }^{35}$ Indonesia, Undang-Undang Perkebunan, UU No. 39 Tahun 2014, LN No. 308 Tahun 2014, TLN No. 5613, Ps. 58.

${ }^{36}$ Terdapat beragam data tentang luas perkebunan sawit dalam kawasan hutan. Menteri Lingkungan dan Kehutanan menyatakan luasnya sebesar 2,3 juta hektare (http://www. mongabay. co.id/2018/10/20/menteri-lingkungan-bakal-evaluasi-23-juta-hektare-kebun-sawit-di-kawasanhutan/). Kajian UGM menunjukkan areal seluas 2,8 juta yang 35 persennya dikelola masyarakat, sedangkan sisanya oleh perusahaan sawit (lihat http:/ / www.mongabay. co.id/2018/11/04/kajian-ugm- 
lem ini juga yang menyandung implementasi ISPO sebagai instrumen wajib untuk usaha perkebunan sawit Indonesia yang berkelanjutan. Direktorat Jenderal Perkebunan Kementerian Pertanian mencatat, dari 11,3 juta hektare lahan perkebunan sawit nasional, masih ada beberapa luasan yang bermasalah. Dari 6,7 juta hektare lahan perkebunan sawit yang dikelola perusahaan besar swasta dan negara, sebanyak 800 ribu hektare terindikasi berada dalam kawasan hutan. Selain itu, merujuk pada catatan Kemenko Bidang Perekonomian, sekitar 2,5 juta hektare lahan belum memiliki kelengkapan Hak Guna Usaha (HGU). ${ }^{37}$

Terlepas dari cakupan ruang lingkup Inpres yang belum menyasar perbaikan tata kelola sawit secara keseluruhan, ${ }^{38}$ instruksi terkait evaluasi perizinan merupakan bagian penting karena berpotensi menyelesaikan berbagai persoalan yang menghambat tata kelola perkebunan sawit berkelanjutan. Inpres Moratorium Sawit masih punya peluang besar sebagai kebijakan dapat menjadi pintu masuk dalam mengurai kompleksitas tata kelola perkebunan sawit yang sangat kompleks sehingga tercipta posisi yang menguntungkan semua pihak.

Lahan yang dijadikan areal pengembangan perkebunan sawit banyak berasal dari "kawasan hutan" yang sebelumnya telah menimbulkan konflik. Bahkan, klaim kawasan hutan seluas 2/3 daratan dapat disebut bentuk perampasan tanah (hak) terdahsyat pasca Indonesia merdeka. Menurut Soedomo, klaim tersebut membuat masyarakat yang tadinya hidup damai menjadi resah karena ditabrak oleh hukum sepihak. ${ }^{39}$ Pemukiman mendadak disebut ilegal, dan banyak desa terjebak oleh kawasan hutan dan seringkali disebut "desa berada dalam kawasan hutan". Wilayah Indonesia tersusun oleh puluhan ribu wilayah desa artinya kawasan hutan sesungguhnya berada di dalam teritori desa, sehingga bukan terkontrol ada sebutan desa "di dalam kawasan hutan".

Konflik lahan di areal pengembangan perkebunan sawit mewakili kasus yang beragam. Konflik lahan tersebut lebih banyak disebabkan tata kelola peme-

28-juta-hektare-kebun-sawit-di-kawasan-hutan-65-milik-pengusaha-solusinya/). Sementara itu, Forest Watch Indonesia (2017) menemukan seluas 8,9 juta hektare kawasan hutan tumpang tindih dengan HPH, HTI, dan perkebunan sawit di 8 provinsi (http:/ / www.mongabay.co.id/2017/12/13/kajian-fwi89-juta-hektare-lahan-tumpang-tindih-di-8-provinsi/).

${ }^{37}$ Anonim, "Mengurai Kendala Skim Berkelanjutan Ala Indonesia", https://www.infosawit.com/ news/8131/mengurai--kendala-skim-berkelanjutan-ala-indonesia, diakses tanggal 31 Desember 2018.

${ }^{38}$ Anonim, "Policy Brief Membumikan Moratorium dan Evaluasi Perkebunan Sawit", http:// sawitwatch.or.id/wp-content/uploads/2019/03/Policy-Brief_Membumikan-Moratorium-dan-Evaluasi-Perkebunan-Sawit.pdf, diakses tanggal 3 Mei 2019.

${ }^{39}$ Anggiana G. Adinugraha, et.al, Tata Kelola Perkebunan Sawit di Indonesia Studi Kasus di Provinsi Riau dan Kalimantan Barat, Cetakan ke-1, (Bogor: Forci Development Fakultas Kehutanan Institut Pertanian Bogor, 2018), hlm. 141-142. 
rintahan dan pengaturan agraria yang buruk. Ketika tata kelola pemerintahan dan pengaturan agraria masih buruk, apapun jenis usaha atau komoditas yang diusahakan berpotensi menghadirkan konflik. Karena itu, penyebab konflik semestinya tidak dialamatkan hanya pada perusahaan perkebunan sawit, tetapi dialamatkan pada buruknya tata pemerintahan dan pengaturan agraria, serta ketimpangan alokasi lahan antara kawasan hutan dan bukan kawasan hutan. ${ }^{40}$

Impian perbaikan tata kelola lahan tentu saja menjadi sangat jauh mengingat mandat KLHK tentang evaluasi izin yang terbatas. Berdasarkan hasil evaluasi, ada lima pemangku kebijakan yakni Bupati dan Gubernur, Kementerian Agraria dan Tata Ruang (ATR/BPN), Menteri LHK, serta Menteri Pertanian yang diberi mandat untuk melakukan 'langkah-langkah tindak lanjut' yang diputuskan dalam 'rapat koordinasi' yang akan diselenggarakan oleh Menko Bidang Perekonomian. Oleh karena itu, penting untuk berpikir melampaui teks kebijakan dengan cara pandang lain supaya tidak terbatas melihat kebijakan hukum secara literal.

Dalam kerangka ini penting untuk mengadopsi Teori Politik Hijau, sehing- ga gerakan sosial memaknai mandat evaluasi perizinan tidak semata sempit sebagai mengevaluasi seluruh perizinan industri. Dengan Teori Politik Hijau John Barry sesuai dengan prinsip komitmen usaha untuk mencapai keberlangsungan ekologi, maka mandat evaluasi perizinan dapat diartikulasikan sebagai upaya tata kelola lahan, sebab selama ini izin hanya satu dari penyebab masalah lainnya.

Pendekatan tersebut dapat dimulai dengan mengaitkan moratorium sawit dengan program reforma agraria. Menurut Tenaga Ahli Utama Kantor Staf Presiden, Usep Setiawan, dari buku khusus arahan KSP, kementerian dan lembaga terkait harus melakukan evaluasi izin usaha perkebunan sawit maupun hutan tanaman industri sebagai langkah prasyarat menuju reforma agraria. Alasannya, sebagian tanah obyek reforma agrarian diimajinasikan berasal dari eks HGU, termasuk HGU terlantar, tak diperpanjang maupun yang berkonflik dengan masyarakat. ${ }^{41}$

Dalam pelaksanaannya, Perpres Reforma Agraria ${ }^{42}$ sama seperti Inpres Moratorium sawit yang dikoordinir Menteri Koordinator Bidang Perekonomian. Perpres Reforma Agraria mengatur soal keberadaan Tim Reforma Agraria Nasional

${ }^{40}$ Ibid.

${ }^{41}$ Lusia Arumingtyas, "Moratorium Sawit Bisa Dorong Percepatan Reforma Agraria”, https:// www.mongabay.co.id/2018/09/04/moratorium-sawit-bisa-dorong-percepatan-reforma-agraria/, diakses tanggal 3 Mei 2019.

${ }^{42}$ Indonesia. Peraturan Presiden tentang Reforma Agraria, Perpres No. 86 Tahun 2018. 
yang diketuai Menteri Koordinator Bidang Perekonomian dan dibantu Gugus Tugas Reforma Agraria (GT RA) yang meliputi GT RA Pusat, Provinsi, dan Kota/Kabupaten. Mekanisme dan tata kerja Tim Reforma Agraria diatur lebih lanjut oleh Peraturan Menteri Koordinator Bidang Perekonomian, sedangkan mekanisme dan tata kerja GT RA diatur dalam Peraturan Menteri (tidak disebutkan). Perpres RA mewajibkan GT RA di tingkat Pusat, Provinsi, dan Kota/Kabupaten dibentuk selambat-lambatnya tiga bulan setelah Perpres tersebut disahkan. Dalam kerangka tersebut jika dapat dipastikan bahwa Tim Kerja dalam Inpres Moratorium Sawit dan GT RA dapat bekerja secara sinergis, serta menjamin bahwa rapat konsolidasi Tim Kerja Inpres Moratorium.

\section{Penutup}

Penulis berpendapat bahwa keterkaitan Inpres Moratorium Sawit dengan kebijakan hijau sesuai dengan Teori Politik Hijau dapat dipahami sebagai:

Pertama, Inpres Moratorium Sawit bukanlah kebijakan hijau sebagaimana dimaksud oleh Teori Politik Hijau. Hal tersebut disebabkan hanya ada satu kriteria Teori Politik Hijau yang dipenuhi oleh kebijakan ini yakni mencapai keberlanjutan ekologis, meski masih dalam tataran imajinasi cita-cita kebijakan ini. Namun kegagalan menjadi kebijakan berkelanjutan, tidak lantas membuat
Inpres Moratorium Sawit tidak bermanfaat. Pelaksanaan Inpres tersebut tetap penting untuk dikawal.

Kedua, Inpres Moratorium Sawit masih memiliki peluang untuk menyelesaikan masalahnya jika kebijakan ini dimaknai menggunakan seperangkat nilai Teori Politik Hijau untuk mengartikulasikannya. Hal tersebut untuk menghindari pemaknaan sempit yang biasanya dilakukan oleh para birokrat dengan membaca literal peraturan hukum. Artikulasi dengan nilai-nilai Teori Politik Hijau dapat digunakan sebagai salah satu cara melampaui teks kebijakan tersebut, salah satunya dengan mengontekskan moratorium dengan reforma agraria. 


\section{DAFTAR PUSTAKA}

\section{Peraturan Perundang-Undangan}

Indonesia. Undang-Undang Perkebunan. UU No. 39 Tahun 2014. LN No. 308 Tahun 2014. TLN No. 5613.

. Peraturan Presiden tentang Reforma Agraria, Perpres No. 86 Tahun 2018.

Instruksi Presiden Republik Indonesia tentang Penundaan Pemberian Izin Baru dan Penyempurnaan Tata Kelola Hutan Alam Primer dan Lahan Gambut. Inpres No. 10 Tahun 2011.

Instruksi Presiden Republik Indonesia tentang Penundaan Pemberian Izin Baru dan Penyempurnaan Tata Kelola Hutan Alam Primer dan Lahan Gambut. Inpres No. 6 Tahun 2013.

. Instruksi Presiden Republik Indonesia tentang Penundaan Pemberian Izin Baru dan Penyempurnaan Tata Kelola Hutan Alam Primer dan Lahan Gambut. Inpres No. 6 Tahun 2017.

. Instruksi Presiden Republik Indonesia tentang Penundaan dan Evaluasi Perizinan Perkebunan Kelapa Sawit Sera Peningkatan Produktivitas Perkebunan Kelapa Sawit. Inpres No. 8 Tahun 2018.

\section{Buku}

Adinugraha, Anggiana G. et.al. Tata Kelola Perkebunan Sawit di Indonesia Studi Kasus di Provinsi Riau dan Kalimantan
Barat. Cetakan ke-1. Bogor: Forci Development Fakultas Kehutanan Institut Pertanian Bogor. 2018.

Barry, John. Green Political Theory. London: Routledge. 2014.

Hartono, Sunaryati. Politik Hukum Menuju Satu Sistem Hukum Nasional. Bandung: Alumni. 1991.

Indrati, Maria Farida. Ilmu PerundangUndangan: Dasar dan Cara Pembentukannya. Yogyakarta: Kanisius. 2007.

Iskandar, J. Kapita Selekta teori Administrasi Negara. Bandung: Puspaga. 2012.

Islamy. Prinsip-prinsip Perumusan Kebijakan Negara. Jakarta: Bumi Aksara. 1997.

Mas'oed, M. Ilmu Hubungan International: Disiplin dan Metodologi. Jakarta: LP3ES. 1994.

MD, Moh. Mahfud. Politik Hukum di Indonesia. Jakarta: Raja Grafindo. 2014.

Nugroho. Kebijakan Publik, Formulasi, Implementasi dan Kebijakan. Jakarta: Gramedia. 2003.

Pepper, David. Environmentalism, dalam Understanding Contemporary (Theoris and the Present). London: SAGE Publication. 2000.

\section{Lain-lain}

Adinugraha, Anggiana G. dkk, Tata Kelola Perkebunan Sawit di Indonesia Studi Kasus di Provinsi Riau dan Kalimantan Barat; Bogor: Forci Development Fakultas Kehutanan Institut Pertanian Bogor. 2018. 
Agustiyanti. "Kementan Klaim Sawit Sumbang Devisa Negara Rp239 Triliun." https://www.cnnindonesia. com/ekonomi/ 20170829150806-92-

238106/ kementan-klaim-sawit-sumbang-devisa-negara-rp239-triliun. diakses tanggal 13 Oktober 2018.

Amalia, Fitri. “Update Harga TBS Kelapa Sawit September 2018, Semakin Membaik." http://jambi.tribunnews.com/2018/09/10/updateharga-tbs-kelapa-sawit-7-23-september-2018-semakin-membaik. diakses tanggal 26 Januari 2019.

Anonim. "Minyak Kelapa Sawit." https://www.indonesia-investments. $\mathrm{com} /$ id/bisnis/komoditas/ minyaksawit/item166. diakses tanggal 13 Oktober 2018.

. "Analisis Substansi Inpres Moratorium Sawit 2018." https:/ / madaniberkelanjutan.id/2018/09/28/analisis-substansi-inpres-moratoriumsawit-2018/. diakses tanggal 28 Januari 2019.

. "Enam Tahun Memperbaiki Tata Kelola Hutan dan Lahan Gambut: Sebuah Evaluasi atas Pelaksanaan Instruksi Presiden Tentang Penundaan Pemberian Izin Baru dan Penyempurnaan Tata Kelola Hutan Alam Primer dan Lahan Gambut." http:/ / www.mongabay.co.id/wp-content/ uploads/2017/05/Kertas-KebijakanMoratorium-dari-Koalisi.pdf. diakses pada tanggal 3 Mei 2019.
"Mengurai Kendala Skim Berkelanjutan Ala Indonesia", https:// www.infosawit.com/news/8131/ mengurai--kendala-skim-berkelanjutan-ala-indonesia. diakses tanggal 31 Desember 2018.

. "Policy Brief Membumikan Moratorium dan Evaluasi Perkebunan Sawit." http://sawitwatch.or.id/wpcontent/uploads/2019/03/ Policy-Brief_Membumikan-Moratorium-dan-Evaluasi-PerkebunanSawit.pdf. diakses tanggal 3 Mei 2019.

. "Policy Brief Rasionalitas Moratorium Sawit." http://sawitwatch.or.id/wp-content/uplo ads/2017/07/ Full-rasionalitas-moratorium-sawit2. pdf. diakses tanggal 2 Januari 2019.

Arumingtyas, Lusia dan Indra Nugraha. "Akhirnya, Inpres Moratorium Perkebunan Sawit Terbit." https:// www.mongabay.co.id/2018/09/20/ akhirnya-inpres-moratorium-perkebunan-sawit-terbit/. diakses tanggal 2 Januari 2005.

Arumingtyas, Lusia. “Moratorium Sawit Bisa Dorong Percepatan Reforma Agraria." https://www.mongabay. co.id/2018/09/04/moratoriumsawit-bisa-dorong-percepatanreforma-agraria/. diakses tanggal 3 Mei 2019.

Dictionary. "Definition of Moratorium from the Cambridge Advanced Learner's Dictionary \& Thesaurus." htt- 
ps://dictionary.cambridge.org/dictionary/english/moratorium. diakses tanggal 2 Januari 2019.

Firmansyah, Nurul. "Moratorium Izin Hutan dan Gambut, Berjilid-jilid (Tanpa) Ada Perbaikan?" https:// www.mongabay.co.id/2017/05/28/ opini-moratorium-izin-hutan-dangambut-berjilid-jilid-tanpa-ada-perbaikan/. diakses tanggal 3 Januari 2019.

Mezariani G, Kania. “Kelapa Sawit: Antara Kebijakan Ketahanan Energi Dan Climate Change Uni Eropa, Serta Respon Pemerintah Indonesia." http:/ / perpustakaan.elsam.or.id/in$\mathrm{d}$ ex $\cdot \mathrm{ph}$ p ? p = s how_d e t a il\&id $=15289 \&$ keywords=kelapa + sawit. diakses tanggal 9 Oktober 2018.

Mongabay Indonesia. “Rangkuman: Melacak Komitmen Presiden Jokowi dalam Pengelolaan Lingkungan di Indonesia." https://www.mongabay. co.id/2016/07/31/rangkumanmelacak-komitmen-presidenjokowi-dalam-bidang-pengelolaanlingkungan-di-indonesia/. diakses tanggal 1 Januari 2019.

Murdiyarso, D. et. al. “Moratorium hutan Indonesia: Batu loncatan untuk memperbaiki tata kelola hutan?" https:// www.cifor.org/library/3631/. diakses tanggal 2 Januari 2019.

Nugraha, Indra. "Menteri Lingkungan Bakal Evaluasi 2,3 Juta Hektar Kebun Sawit di Kawasan Hutan." https:// www.mongabay.co.id/2018/10/20/ menteri-lingkungan-bakal-evaluasi- 23-juta-hektar-kebun-sawit-di-kawasan-hutan/. diakses tanggal 4 Januari 2019.

Purningsih, Dewi. "Inpres Moratorium Perkebunan Sawit Donong Penyerapan CPO." https:/ / www.greeners. $\mathrm{co} /$ berita/inpres-moratorium-perkebunan-sawit-dorong-penyerapancpo/. diakses tanggal 3 Mei 2019.

Saputra, Wiko. "Selamat Datang Moratorium Sawit!" Tempo. 26 September 2018.

Saturi, Sapariah. "Akhirnya, Inpres Moratorium Perkebunan Sawit Terbit". https: / / www.mongabay.co. $\mathrm{id} / 2018 / 09 / 20 /$ akhirnya-inpresmoratorium-perkebunan-sawit-terbit/. diakses tanggal 2 Januari 2019.

Sihombing, Martin. "Beginilah Geliat Industri Sawit, Si Emas Hijau." http:// industri.bisnis.com / read /20180205/99/734393/beginilahgeliat-industri-sawit-si-. diakses tanggal 13 Oktober 2018.

Spross, Hans. "Uni Eropa Tunda Larangan Sawit Hingga 2030," https:// www.dw.com/id/uni-eropa-tundala ran gan - s a wit - h in g g a 2030/a-44315242. diakses tanggal 26 Januari 2019.

Suastha, Riva. "WALHI Tagih Janji Jokowi Selesaikan Konflik Lingkungan." https:// www.cnnindonesia.com/ nasional/20160602195942-20135483/ walhi-tagih-janji-jokowi-selesaikankonflik-lingkungan. diakses tanggal 1 Januari 2019. 
Susanto, Ichwan. "Presiden Jokowi Bubarkan BP-REDD dan DNPI." https: / / sains.kompas.com / $\mathrm{read} / 2015 / 01 / 28 / 18352191 /$ Presiden.Jokowi.Bubarkan.BP-REDD. dan.DNPI. diakses tanggal 1 Mei 2019.

Tobing, Letezia. "Perbedaan Keputusan Presiden Dengan Instruksi Presiden." https://www.hukumonline. com/klinik/detail/1t50cf39774d2ec/ perbedaan-keputusan-presidendengan-instruksi-presiden/. diakses tanggal 1 Januari 2019.

Waluyo, Joko. “Urgensi Kebijakan Moratorium Perkebunan Kelapa Sawit di Indonesia", https://www.tuk.or. id/2017/09/17/urgensi-kebijakanmoratorium-perkebunan-kelapasawit-di-indonesia/. diakses tanggal 3 Mei 2019. 